\title{
Data and information in online environments
}

\section{Dados e informações em ambientes online}

\author{
Carlos Luis GONZÁLEZ-VALIENTE1 (iD) 0000-0002-1836-5257 \\ Douglas Dyllon Jeronimo de MACEDO² (D) 0000-0002-3237-4168
}

Online social environments have opened up new opportunities for data and information analysis and processing. The high volume of content generated daily imposes a challenge regarding the design of indicators, procedures, and techniques for measuring these data. Behind the study of these topics, lie theories and models mainly coming from the information, communication, and computer sciences, three broad disciplinary contexts that converge in the effective design of Information and Communication Technologies and their relationship with people.

Due to the features and benefits present in online environments, there are currently other possibilities to study the mention of scientific objects in social media (Costas, 2017), which have generated new methods to analyze the quality of published research (Repiso; Moreno-Delgado; Aguaded, 2020). This analysis is not only limited to scientific objects, but it includes the formation of opinions about certain events of economic, social, and political life (Lee et al., 2018), as well as learning and knowledge construction (Holtz; Kimmerle; Cress, 2018). The large volume of data produced from all social interactions requires to be processed through methods and software packages that allow us to interpret behaviors, predict events, and identify patterns (Bonenfant; Meurs, 2020).

Many of these aspects, as Rauch (2016) states, are not only of interest to science, since this phenomenon also affects parts of our lives nowadays. For this reason, the EAI International Conference on Data and Information in Online Environments (DIONE) was created, a conference that had its first edition on April 17, 2020 in Florianópolis, Brazil, and which counted on the support of the Postgraduate Program of Information Science of the Federal University of Santa Catarina. The EAI DIONE 2020 Conference emerges to discuss possible solutions regarding the use and analysis of information, evaluation of science, and data processing in online environments. This conference brought together attendees from Brazil, Canada, Peru, Slovakia, Portugal, the United States, and China, who presented papers related to information studies, computing, social network analysis, medical informatics, communication, among others.

On this occasion, we grant a special issue derived from the event, based on a selection of some of the most relevant presentations on communication and information. Alicia Moreno-Delgado and colleagues are presenting an article where the feasibility of ranking universities is determined by considering the number of graduates employed in top companies through Linkedln. Using the Lattes Platform, Monique de Oliveira Santiago and

\footnotetext{
1 European Alliance for Innovation, Publications Department. Vazovova 3, 811 07, Bratislava, Slovakia. Correspondence to: C.L. GONZÁLEZ-VALIENTE. E-mail: <carlos.valiente89@gmail.com>.

2 Universidade Federal de Santa Catarina, Programa de Pós-Graduação em Ciência da Informação, Departamento de Ciência da Informação. Florianópolis, SC, Brasil.
}

How to cite this article

González-Valiente, C.L.; Macedo, D.D.J. Data and information in online environments. Transinformação, v. 32, e200073, 2020. https://doi.org/10.1590/2318-0 $889202032 \mathrm{e} 200073 \mathrm{e}$ 
colleagues analyze the scientific production of women in Brazil. Meanwhile, Alexandre Ribas Semeler and Adilson Luiz Pinto have generated a literature review to introduce Data Librarianship as a solid research field. With the aim to improve art information and user behavior factors and their effect on art communication and development, Dongsheng Zhang and Daodong Sun propose an S-SEIR art communication and development model based on social network. Meanwhile, Enrique Muriel-Torrado and Danielle Borges Pereira analyze the correlation of false news and misinformation concepts with Fogg's Behavior Model. The intellectual structure of Green Chemistry is mapped by Leonardo Voctor Marcelino and colleagues, whose aim is to broaden the understanding of this field using cocitation and network analysis. Finally, Liang Wang and Cheng Dong propose a multicultural media integration model based on multi agent collaboration, which combines the life cycle of multicultural media models in the network's public spaces of opinion.

On behalf of the Organizing Committee of EAI DIONE 2020, we appreciate the publication opportunity offered by the Editorial Board of TransInformação. We finally invite all you to read the articles contained in this special issue and to continue contributing on these topics.

\section{References}

Bonenfant M.; Meurs M. J. Collaboration between social sciences and computer science: toward a cross-disciplinary methodology for studying big social data from online communities. In: Hunsinger J.; Allen M.; Klastrup L. (ed.). Second International Handbook of Internet Research. Dordrecht: Springer, 2020. p. 47-63. Doi: https://doi.org/10.1007/978-94024-1555-1_39.

Costas, R. Towards the social media studies of science: social media metrics, present and future. Bibliotecas. Anales de Investigación, v. 13, n. 1, p. 1-5, 2017.

Holtz, P.; Kimmerle, J.; Cress, U. Using big data techniques for measuring productive friction in mass collaboration online environments. International Journal of Computer-Supported Collaborative Learning, v. 13, n. 4, p. 439-456, 2018. Doi: https:// doi.org/10.1007/s11412-018-9285-y.
Lee, S. et al. Understanding the majority opinion formation process in online environments: an exploratory approach to Facebook. Information Processing and Management, v. 54, n. 6, p. 1115-1128, 2018. Doi: https://doi.org/10.1016/j. ipm.2018.08.002.

Rauch, W. Technological change in information and communication: consequences for science. In: Bednar-Friedl, B.; Kleinert, J. (ed.). Dynamic approaches to global economic challenges. Cham: Springer, 2016. p. 131-140. Doi: https://doi. org/10.1007/978-3-319-23324-6_8.

Repiso, R.; Moreno-Delgado, A.; Aguaded, I. Factors affecting the frequency of citation of an article. Iberoamerican Journal of Science Measurement and Communication, v. 1, n. 1, p. 1-6, 2020. Doi: https://doi.org/10.47909/ijsmc.08. 